\title{
Understanding the Convenience of Mobile Banking Adoption for Banking Customers in the Millennials Generation
}

\author{
Doddy Adhimursandi; Suharno; Yohanes Kuleh
}

Faculty of Economics and Business, Mulawarman University, Indonesia

http://dx.doi.org/10.18415/ijmmu.v8i12.3259

\begin{abstract}
This study aims to see how different aspects of online convenience affect the desire to utilize mobile banking. The population and sample of this study were 240 customers who are millennials and use M-Banking in 3 big cities in East Kalimantan Province, namely Samarinda, Balikpapan, and Tenggarong. According to the findings of this study, access convenience, search convenience, evaluation convenience, and post-benefit convenience all impact the desire to use M-Banking. Next, the result shows that the intention to adopt M-Banking affects the adoption of M-Banking. The results of this study can be used as suggestions for banks in improving services using the M-banking platform to make it more comfortable.
\end{abstract}

Keywords: M-Banking Adoption Intention; M-Banking adoption; Online Convenience; Mobile Banking

\section{Introduction}

The banking business is heavily influenced by the use of information systems. Given how extensively the banking industry relies on information technology to collect, process, analyze, and present information to clients, this effect has had a significant impact. The success of an information system depends on the ease and use of system users to technology because technology helps individuals complete their tasks. The development of the use of information technology by banks, among others, through Mbanking facilities, Not only do M-banking platforms serve users, but they also benefit banks in several ways. Banks favored the M-banking channel due to its cost-effectiveness and increased client reach (Shankar \& Jebarajakirthy, 2019). In comparison to other banking channels, users prefer M-banking due to the convenience of accessing services from any location (Shankar \& Jebarajakirthy, 2019). Additionally, in-branch banking customers may access banking services only during business hours. Whereas, because M-banking systems are ubiquitous, consumers can access financial services at any time. Similarly, consumers are required to visit a branch to obtain banking services, whereas M-banking platforms enable consumers to obtain banking services from any location. Thus, banks can broaden their reach by providing banking services through mobile banking systems. Banking consumers are incredibly busy in today's world; They use mobile banking to cut down on the time it takes to complete banking transactions. Thus, based on the preceding, convenience appears to be a factor in adopting and using Mbanking. Without data on the effect of online convenience on client adoption of online service delivery channels such as mobile banking, financial service providers face a challenge. Banks are interested in enhancing online convenience through M-banking platforms to increase M-banking acceptance and usage while maintaining banking services via the M-banking platform. However, in the context of mobile commerce, particularly M-banking, various effects of online convenience on consumers, such as intention to adopt or adaptive behavior, have been neglected. Due to the unique characteristics of mobile banking, 
such as increased ubiquity and localization (Koenig Lewis et al., 2010), it is necessary to investigate the impact of multidimensional online convenience on customer adoption behavior. On the other hand, the literature has yet to demonstrate how various dimensions of online convenience influence an individual's proclivity to use mobile banking services. This knowledge gap was the impetus for this investigation. Thus, the purpose of this study is to determine how online convenience affects consumer adoption and usage of mobile banking services and which aspects of online convenience are critical in the context of M-banking adoption behavior.

\section{Literature Review}

\section{M-Banking}

Information technology advancements have reshaped the traditional retail banking delivery system (Laukkanen, 2016). Branch banking, automated teller machines (ATMs), internet banking, and mobile banking are just a few of the ways that financial institutions now offer their products and services. Nonetheless, due to its increased ubiquity and localization, M-Banking is the most promising and innovative of all channels (Koenig-Lewis et al., 2010). M-Banking is distinguished by its ability to determine the mobile user's geographical location and provide location-specific banking services (for example, informing the customer of the location's currency exchange rates, ATM availability, and money transfer facilities) (Junglas \& Watson, 2006). M-Banking is widely regarded as the most flexible and convenient channel for accessing banking services due to these distinguishing characteristics. M-Banking is now being used as a strategic tool by financial institutions to meet customer expectations and maintain a competitive edge in the banking industry (Tam \& Oliveira, 2016). M-Banking is a mobile banking extension of online banking that allows customers to conduct all banking transactions using their mobile devices (Laukkanen, 2016). M-Banking services benefit consumers, banks, and telecommunications service providers more than ever before (Shareef et al., 2018). As a result, M-Banking has emerged as one of the most valuable and promising mobile commerce applications in recent years (Laukkanen, 2016). Numerous researchers have examined the adoption of M-Banking (Shankar \& Kumari, 2016); (Shareef et al., 2018). M-Banking benefits both banks and consumers; consequently, numerous studies have been conducted in the literature to examine adoption intention behavior in the M-Banking context (Shankar, Jebarajakirthy, et al., 2020). This is due to the importance of convenience when using the M-Banking platform to access banking services (Shareef et al., 2018), and banks are interested in learning how to increase M-Banking adoption. Consequently, it is essential to know how online convenience affects MBanking adoption behavior.

\section{Online Convenience}

Consumers' desire for convenience has grown as they dedicate less time to shopping and more to other activities, and their attention has turned to online shopping. (Kumar \& Kashyap, 2018). Consumers' limited available time encourages them to seek out ways to save time and effort when making purchases (Berry \& Cooper, 1990). (Copeland, 1923) created the term "convenience" to describe the amount of time and effort necessary to purchase consumer goods. Thus, the cost to customers of their time and effort spent browsing in a retail setting can be characterized as retail convenience. These non-monetary consumer resources of time and effort are regarded as non-monetary expenses that influence purchase behavior in the marketing literature (Bender, 1964). (Herrmann \& Beik, 1968). Recognizing this need, retailers have concentrated their efforts on providing services that expedite and simplify the purchasing process for consumers (Shaheed, 2004).

This study aimed to determine how the dimensions of convenience affect the intention to adopt M-Banking. Consumers adopt and use mobile banking channels to save time and effort (Shankar \& Rishi, 2020). Convenience is a significant factor in consumer preferences for M-Banking and conducting transactions (Kaura, 2013); (Shankar \& Rishi, 2020). With this application, consumers can access various information about banking products and perform financial transactions anywhere (Shankar, 
Jebarajakirthy, et al., 2020). consumers do not need to come to the branch to make transactions offline, which takes time, effort, and costs. Consumers can access banking services through the M-Banking platform at any time, without the need to visit the Bank directly, which requires time and effort. As a result, consumers prefer to do banking transactions through online banking platforms. Search convenience (Benoit et al., 2017), access convenience (Roy et al., 2018), evaluation convenience (Shankar \& Rishi, 2020), benefit convenience (Shankar \& Rishi, 2020), transaction convenience (Jiang et al., 2013), and post-benefit convenience (Duarte et al., 2018) are the main convenience factors that attract users to use the M-Banking platform to get banking services.

\section{Hypothesis Development}

\section{Access Convenience}

"Convenience of access" refers to "consumers' perceptions of the least amount of work and time required to receive services" (Benoit et al., 2017). However, in the context of online services, the primary components of online access convenience are website accessibility, product availability across online platforms, and time and location flexibility (Duarte et al., 2018). Access convenience is a critical factor in determining overall online service convenience in the context of online service delivery (Jiang et al., 2013). Due to inaccessibility and lack of awareness of M-Banking services, consumers spend time and effort visiting banks and getting banking services (Shankar \& Datta, 2018). Online banking must use a computer, laptop, or tablet, while mobile banking customers can access banking services anytime and anywhere. Banks should educate their clients via marketing on various digital and social media channels since a lack of understanding contributes considerably to the delayed uptake of M-Banking services. To improve accessibility, banks should also offer M-Banking services to customers who do not have access to the Internet. M-Financial platforms can be used in various ways to access banking services. As a result, customers see mobile banking as more convenient than traditional branch banking and plan to use it. Consumers also benefit from the flexibility of M-Banking platforms in terms of schedule and geographic location. As a result, people prefer to use mobile devices to do financial activities (Shankar, Datta, et al., 2020). As a result, we propose the following:

H1. Access convenience positively significant impacts M-Banking adoption intention.

\section{Search Convenience}

(Beauchamp and Ponder, 2010) Search convenience is defined as "the ease with which shoppers identify and select items for purchase." The Internet has provided retailers with a variety of tools to improve their communication with potential clients by reinforcing their ability to provide tailored information, either by placing it on their website and using paid advertising to redirect traffic or by disseminating information and creating a buzz in social media, assisting them in identifying and selecting the right business relationships (Kollmann et al., 2012). Consumers benefit psychologically from these increased tools because they avoid wasting time by avoiding crowds, lowering waiting times, and exerting effort driving to physical sites (Beauchamp and Ponder, 2010).

Consumers can quickly and easily access banking information via online banking platforms (Wang et al., 2018). Consumers should visit branches to get information about banking services. This takes time, effort, and money, while the M-Banking platform allows consumers to get information about banking services anytime and anywhere (Huang et al., 2009). M-Banking platforms also allow clients to read online feedback from previous customers (Lee \& Jin Ma, 2012), which assists them in selecting the most appropriate banking services. Consumers are more likely to adopt M-Banking platforms if they believe they can easily access information about banking services. As a result, we make the following proposal:

H2. Search convenience positively significant impacts M-Banking adoption intention. 


\section{Evaluation Convenience}

During the review process, convenience was described as clear and complete product availability (Jiang et al., 2013). Product evaluation, price comparison, product performance, and brand comparison have essential roles in consumer purchasing decisions (Duarte et al., 2018). Consumers often evaluate product specifications in depth before making a purchase decision (Gensler et al., 2012). Consumers collect information about bank products and compare it with the time and cost of products at other banks. Meanwhile, consumers can quickly obtain detailed information about products and compare the performance of similar banking products through the M-Banking platform (Shankar, Datta, et al., 2020). In addition, consumers can access buyers' previous experiences with product quality, which allows them to make more informed purchasing decisions (Shankar, Jebarajakirthy, et al., 2020). In addition, consumers can discuss with other bank customers the advantages and disadvantages of certain products so that product assessments are more accurate. Through the mobile banking platform, consumers can access the latest information, online reviews, and relevant content, helping them choose the most appropriate banking product (Jun \& Palacios, 2016). From this explanation, we propose the following:

H3. Evaluation convenience positively significant impacts M-Banking adoption intention.

Transaction Convenience

"The speed and ease with which consumers can execute a transaction" is what the phrase "transaction convenience" alludes to (Benoit et al., 2017). Convenience is defined as minimizing the time and effort required to complete a transaction (Jiang et al., 2013). Convenient online transactions are characterized by an easy checkout process, an uninterrupted process, transaction confirmation, a variety of options, and price inconsistency (Jiang et al., 2013); (Reimers \& Chao, 2014); (Mahapatra, 2017). Consumers who need to conduct transactions in a branch banking environment must visit the branch, which takes time, effort, and money. Additionally, consumers must queue for banking services.

Additionally, consumers may conduct transactions only during designated banking hours (Shankar \& Kumari, 2016). In comparison, consumers who use M-Banking can conduct transactions at any time and from any location with just a few clicks (Wolfinbarger \& Gilly, 2001). Consumers can also use the M-Banking platform to schedule future transactions and make multiple transactions simultaneously and swiftly (Shankar, Jebarajakirthy, et al., 2020). Additionally, if a customer has a problem with a transaction or fails, they can contact customer service to fix the issue using a toll-free number, live chat, or email. As a result, we propose the following:

H4: M-Banking adoption intention is positively influenced by transaction convenience.

\section{Benefit Convenience}

The term "benefit convenience" refers to "the amount of time and effort required to obtain the service's primary benefits" (Berry et al., 2002). The benefit's convenience is enhanced by immediate possession, timely performance of promised services, and the attitudes of bank workers (Jiang et al., 2013). The time disparity between purchasing and receiving things via online platforms produces ambiguity about possession and a perceived delay in product delivery (Noble et al., 2005); (Ahmad \& Sun, 2018). On the other hand, consumers do not have to visit a physical store to acquire a product via online platforms. As a result, they can access the services from anywhere with a few clicks (Jiang et al., 2013). Users must visit banks to access financial services, and in some cases, consumers may be required to visit banks multiple times to obtain a specific service, which requires time and effort. Consumers can use M-Banking platforms to get financial services right away, saving time and effort (Alba et al., 1997). Consumers may occasionally require immediate access to banking services, but in a branch banking environment, they can do so only during banking hours. They can conduct transactions at any time via mobile banking platforms (Laukkanen, 2016). 
Furthermore, clients can only use banking services during specific hours, whereas M-Banking systems allow them to use banking services at any time. Furthermore, clients can only use banking services during specific hours, whereas M-Banking systems allow them to use banking services at any time (Shankar, Datta, et al., 2020). Thus, convenience may be a factor in consumers adopting M-Banking services. As a result, we propose the following:

H5: M-Banking adoption intention is positively influenced by benefit convenience.

\section{Post-Benefit Convenience}

Post-benefit convenience is the time and effort required to contact a particular service provider (Berry et al., 2002). Consumer perceptions of a company's services are strongly influenced by its aftersales service (Jiang et al., 2013). Consumers expect fast and practical solutions to problems after using the service (Duarte et al., 2018). Consumers who transact with banks must visit the branch to solve the problem (Kaura, 2013); This requires extra time and effort. Customers can more easily contact customer service by using M-Banking. In addition, unlike banking transactions, the M-Banking platform allows a choice of ways to contact bank service providers, including email, live chat, and toll-free telephone (Shankar, Datta, et al., 2020). On the M-Banking platform, consumers can also verify the status of their complaints in a few clicks, which cannot be done in banking (Shankar \& Kumari, 2016). We propose the following hypothesis:

H6. M-Banking adoption intention is positively influenced by post-benefit convenience.

\section{M-Banking Services Usage}

The intention to use services has been proposed as a direct antecedent of actual utilization (Ajzen, 1991). As a result, several studies have suggested that the intention to utilize M-Banking has a considerable impact on actual M-Banking usage (Thakur \& Srivastava, 2013); (Sobti, 2019); This research supports the proposal. Consumers will continue to use M-Banking platforms to obtain banking services if they intend to use M-Banking services and believe they are a good fit for their banking needs (Shankar \& Datta, 2018). We propose the following hypothesis based on the same:

H7. The intention to adopt M-Banking has a significant impact on M-Banking adoption.

Based on the above exposure, the empirical model in this study is presented in the following figure:

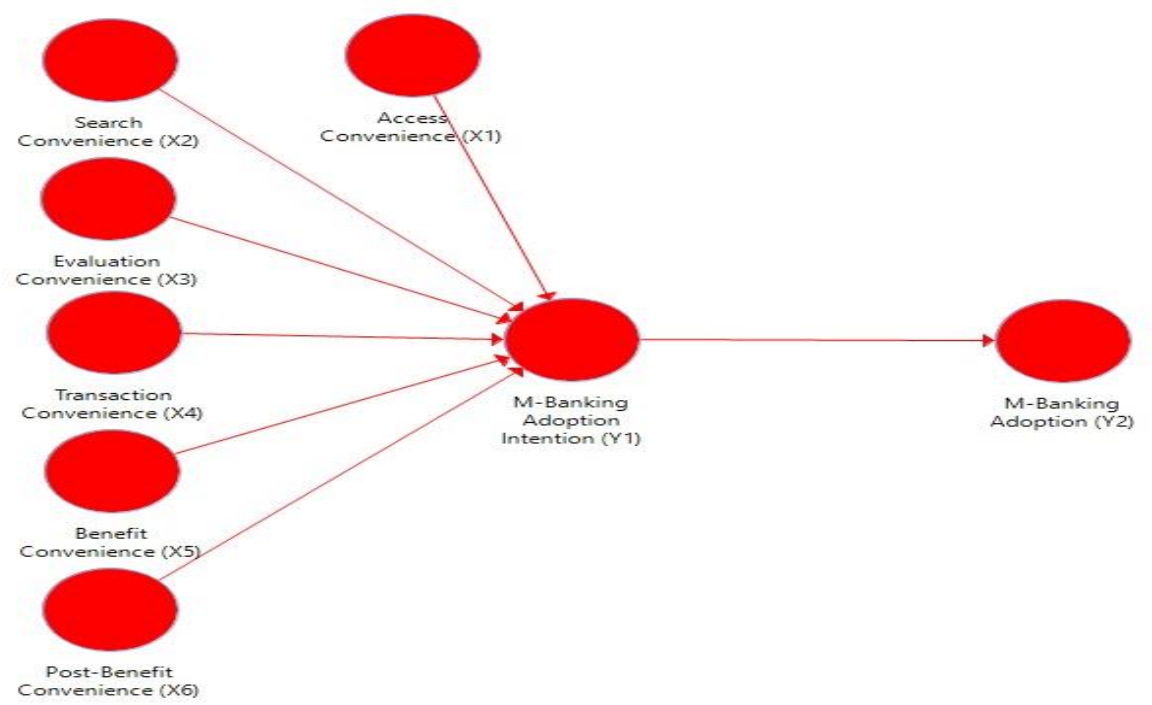

Figure 1. Research Framework 


\section{Research Methods}

This research is classified as quantitative because it employs survey and questionnaire methods. This study's population and sample were all bank customers who use mobile banking in three major cities in East Kalimantan (Indonesia), specifically Samarinda, Balikpapan, and Tenggarong, totaling 240 millennial respondents. Individuals born between 1981 and early 2000 were classified as members of the millennial generation, sometimes known as the Y or Z generation (KIM \& YANG, 2020). In this study, the model used is SEM PLS.

The indicators in each variable were quantified using a Linkert scale ranging from 1 to 5 , with Strongly Disagree $=1$ to Strongly Agree $=5$. M-Banking Adoption consists of three items (Bhattacherjee, 2001); M-Banking Adoption Intention consists of three items (Fishbein \& Ajzen, 1975); Access Convenience consists of three items (Jiang et al., 2013); Search Convenience consists of three items (Beauchamp and Ponder, 2010); Evaluation Convenience consists of three items, and Transaction Convenience consists of three items (Chang et al., 2010).

\section{Result}

\section{Results for Validity Test and Research Indicator Reliability}

Convergent and discriminant validity tests are used to assess the testing model. Construction reliability testing necessitates Cronbach's alpha and composite reliability ratings. Assume that the indicators in the PLS model all match the convergent validity, composite reliability, and discriminant validity requirements. The PLS analysis' results can then be utilized to test research ideas.

\section{Convergent Validity}

Convergent validity requires a high degree of correlation between tests with identical or similar constructs. Convergent validity is determined by comparing the loading factor value of each indicator to the constructed value. The magnitude of the factor loading is significant if it is greater than 0.70 in correlation with the construction being measured. A value of 0.50 to 0.60 , on the other hand, is sufficient for research in the early stages of developing a measurement scale (Vincenzo Esposito Vinzi et al., 2010). (Joseph F. Hair and colleagues, 2016). The minimum factor loading obtained in this study is 0.7, assuming that each construct has an AVE score of 0.5. (2016) (Hair et al.). Several indications with a loading factor value less than 0.7 should be deleted, according to the results of the Smart PLS data processing. Loading factor, Cronbach's alpha, and composite reliability are all words that can be used interchangeably.

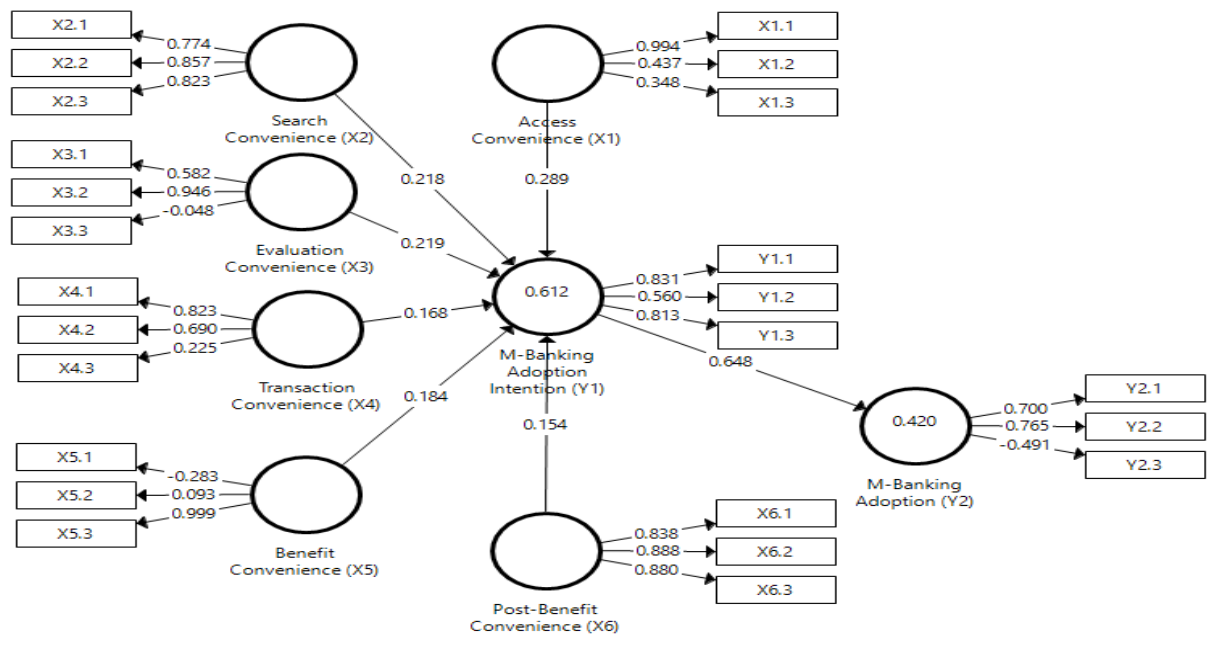

Figure 2: Smart PLS output 
According to Figure 2, several indicators have a factor loading value of less than 0.7, necessitating their removal until the factor loading value meets the researcher's requirements. The final result of the loading factor value exceeding 0.7 is shown in Figure 3.

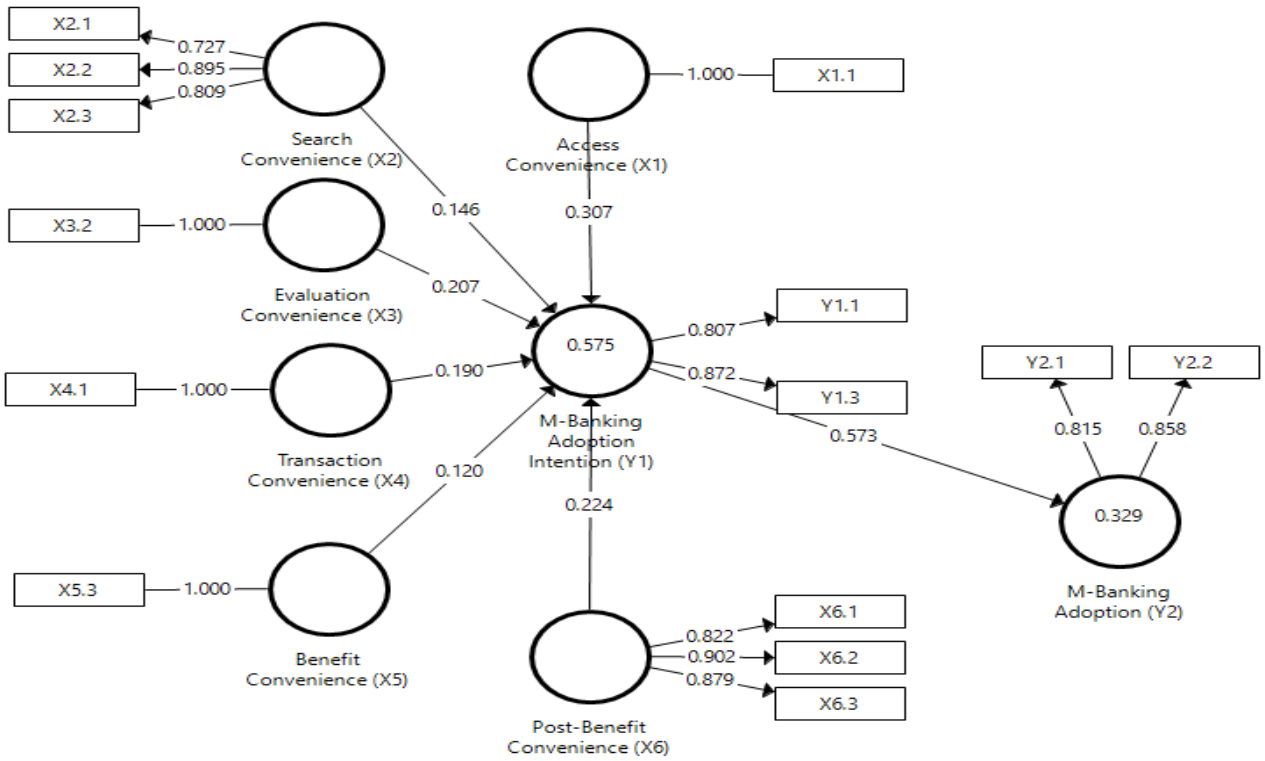

Figure 3: Smart PLS Final Output

According to the Smart PLS output model in Figure 3, all research variable analysis model indicators exceeded the required loading factor of 0.7 .

Table 1. The measuring model's summary

\begin{tabular}{|c|c|c|}
\hline Construct & Statements & FL \\
\hline $\begin{array}{l}\text { Access convenience }(\mathrm{AVE}= \\
1.0, \mathrm{CR}=1.0, \alpha=1.0)\end{array}$ & I can access mobile banking services at any time. & 1.0 \\
\hline $\begin{array}{l}\text { Search convenience }(\mathrm{AVE}= \\
.66, \mathrm{CR}=.85, \alpha=.75)\end{array}$ & $\begin{array}{l}\text { It's simple to use a mobile banking platform. } \\
\text { I can easily find what I am looking for via a mobile banking } \\
\text { platform. } \\
\text { The mobile banking platform is an excellent source of information. }\end{array}$ & $\begin{array}{l}.72 \\
.89 \\
.81\end{array}$ \\
\hline $\begin{array}{l}\text { Evaluation convenience (AVE } \\
=1.0, \mathrm{CR}=1.0, \alpha=1.0)\end{array}$ & $\begin{array}{l}\text { The mobile banking platform provides enough information to } \\
\text { distinguish between different products. }\end{array}$ & 1.0 \\
\hline $\begin{array}{l}\text { Transaction convenience (AVE } \\
=1.0, \mathrm{CR}=1.0, \alpha=1.0)\end{array}$ & $\begin{array}{l}\text { The transaction on the mobile banking platform is simple for me to } \\
\text { complete. }\end{array}$ & 1.0 \\
\hline $\begin{array}{l}\text { Benefit convenience (AVE }= \\
1.0, \mathrm{CR}=1.0, \alpha=1.0)\end{array}$ & $\begin{array}{l}\text { It's simple to use the mobile banking platform to access banking } \\
\text { services. }\end{array}$ & 1.0 \\
\hline $\begin{array}{l}\text { Post-benefit convenience (AVE } \\
=.75, \mathrm{CR}=.90, \alpha=.84)\end{array}$ & $\begin{array}{l}\text { Any issues I've had with the mobile banking platform have been } \\
\text { quickly resolved. } \\
\text { Getting a follow-up service through a mobile banking platform is } \\
\text { simple for me. } \\
\text { Mobile banking platforms are an excellent resource for me when I } \\
\text { have questions about banking services. }\end{array}$ & $\begin{array}{l}.82 \\
.90 \\
.88\end{array}$ \\
\hline $\begin{array}{l}\text { Mobile banking adoption } \\
\text { intention }(\mathrm{AVE}=.71, \mathrm{CR}=.83 \text {, } \\
\alpha=.59)\end{array}$ & $\begin{array}{l}\text { In the future, I intend to use mobile banking. } \\
\text { I anticipate using mobile banking in the future. }\end{array}$ & $\begin{array}{l}.81 \\
.86\end{array}$ \\
\hline $\begin{array}{l}\text { M-Banking Adoption (AVE }= \\
.70, \mathrm{CR}=.82, \alpha=.57)\end{array}$ & $\begin{array}{l}\text { I will continue to use the M-Banking platform to access services. } \\
\text { I prefer to conduct banking transactions via M-Banking. }\end{array}$ & $\begin{array}{l}.81 \\
.86\end{array}$ \\
\hline
\end{tabular}

Notes: "FL-Factor Loading, $\alpha$-Cronbach's alpha, CR-Construct reliability, AVE $=$ Average variance extracted." 


\section{Evaluation of Structural Model}

The structural model shows how well predicted links between latent or construct variables hold up over time. The test results showed a 0.57 link between mobile banking adoption intention and access convenience, search convenience, assessment convenience, transaction convenience, benefit convenience, and post-benefit convenience. According to this result, endogenous variables (X1-X6, Y1) can explain 57 percent of the variance in mobile banking adoption intention. Access convenience, search convenience, assessment convenience, transaction convenience, benefit convenience, post-benefit convenience, and intention to use mobile banking all had R-Square values of 0.33 . This means that variables can explain $33 \%$ of the M-Banking Adoption components investigated in this study.

\section{Hypothesis Test}

Hypothesis testing is conducted after ensuring that the construct's measurement model is reliable and valid. This study conducts hypothesis testing on a structural or inner model that demonstrates a direct or indirect relationship between exogenous and endogenous latent variables. The significance level of the path coefficient is determined by resampling or bootstrapping 500 times (Joseph F. Hair et al., 2016). The $\mathrm{t}$-test is used with a confidence level of $95 \%$ and a significance level of $5 \%$. If the $t$ value is greater than the t-table value for the two-tailed test, namely 1.96, the hypothesis is accepted. Table 2 shows the results of the bootstrapping procedure.

Table 2. The result of the structural model

\begin{tabular}{|l|c|c|c|}
\hline \multicolumn{1}{|c|}{ Proposed hypothesis } & $\begin{array}{c}\text { Original } \\
\text { Sample }\end{array}$ & $\begin{array}{c}\mathrm{T} \\
\text { Statistics }\end{array}$ & P Values \\
\hline Access convenience $\rightarrow$ M-Banking adoption intention & .31 & 5.71 & .00 \\
\hline Search convenience $\rightarrow$ M-Banking adoption intention & .15 & 2.40 & .02 \\
\hline Evaluation convenience $\rightarrow$ M-Banking adoption intention & .21 & 3.73 & .00 \\
\hline Transaction convenience $\rightarrow$ M-Banking adoption intention & .19 & 3.05 & .00 \\
\hline Benefit convenience $\rightarrow$ Manking adoption intention & .12 & 1.70 & .09 \\
\hline Post-benefit convenience $\rightarrow$ M-Banking adoption intention & .22 & 2.97 & .00 \\
\hline M-Banking adoption intention $\rightarrow$ M-Banking adoption & .57 & 18.83 & .00 \\
\hline
\end{tabular}

The following possible inferences can be reached based on the results in Table 2:

a) With a path coefficient of 5.71 and a p-value of 0.00 , access convenience (X1) has a positive and significant effect on M-Banking adoption intention (Y1).

b) With a path coefficient of 2.40 and a p-value of 0.02 , search convenience (X2) positively and significantly affects M-Banking adoption intention (Y1). Thus, the hypothesis is accepted.

c) The convenience of evaluation (X3) has a positive and significant effect on M-Banking adoption intention (Y1), with a path coefficient value of 3.73 and a p-value of 0.00 , indicating that the hypothesis is accepted.

d) Transaction convenience (X4) has a positive and statistically significant effect on M-Banking adoption intention (Y1), with a path coefficient of 3.05 and a p-value of 0.00 , indicating that the hypothesis is accepted.

e) Benefit convenience (X5) has a positive but non-significant effect on M-Banking adoption intention (Y1), with a path coefficient value of 1.70 and a p-value of 0.09 , rejecting the hypothesis.

f) Post-benefit convenience (X6) has a positive and statistically significant effect on M-Banking adoption intention (Y1), with a path coefficient of 2.97 and a p-value of 0.00 , indicating that the hypothesis is accepted.

g) With a path coefficient value of 18.83 and a p-value of 0.00 , M-Banking adoption intention (Y1) has a positive and significant effect on M-Banking adoption (Y2). Thus, the hypothesis is accepted. 


\section{Discussion}

The results of the study explain the relationship between the eight variables.

First, we will look at how access to convenience affects M-Banking adoption intentions. According to statistical analysis, the relationship between these two variables is positive and significant. The primary indicator of Access convenience is that customers can access mobile banking services at their convenience. Numerous studies, including (Jiang et al., 2013); (Duarte et al., 2018).

Second, the effect of search convenience on the intention to adopt M-Banking. According to statistical analysis, the relationship between these two variables is positive and significant. The primary indicator of convenience in Search is that customers can access mobile banking services at any time. Numerous studies, including (Jiang et al., 2013); (Duarte et al., 2018).

Thirdly, the impact of ease of evaluation on the desire to use M-Banking The relationship between these two variables is positive and significant, according to statistical analysis. The primary indicator of convenience in the evaluation process is whether the mobile banking platform provides enough information to differentiate between products. Several studies have been conducted, including (Jiang et al., 2013); (Duarte et al., 2018).

Fourth, the effect of transaction convenience on the intention to adopt M-Banking. According to statistical analysis, the relationship between these two variables is positive and significant. The primary metric for transaction convenience is how easy it is for customers to complete transactions via the mobile banking platform. Numerous studies (Farida, 2016) corroborate the findings of this study (Mehmood \& Najmi, 2017).

The fifth influences Benefit convenience on M-Banking adoption intention. According to statistical analysis, there is no significant relationship between these two variables. The findings of this study are not supported by multiple studies (Chang et al., 2010); (Jebarajakirthy \& Shankar, 2021).

The sixth factor affects the intention to adopt M-Banking based on post-benefit convenience. According to statistical analysis, the relationship between these two variables is positive and significant. The most important metric for post-benefit convenience is the ease with which customers can obtain follow-up services via the mobile banking platform. Numerous studies (Jiang et al., 2013) corroborate the findings of this study (Duarte et al., 2018).

The seventh influences M-Banking adoption intention on M-Banking adoption. According to statistical analysis, the relationship between these two variables is positive and significant. The indicator that has the highest score is the adoption of M-Banking, which will be used in the future. Several studies support the findings of this study (Shankar \& Rishi, 2020).

\section{Conclusion}

Convenience can be a deterrent to M-Banking adoption. According to test results and statistical analysis, convenience, access, Search, assessment, transaction, and post-benefit can improve M-Banking adoption intention. The desire to use mobile banking might be increased. The following are some suggestions for M-Banking adoption:

1. Almost all variables have a favorable impact on the intention to use M-Banking, allowing the Bank to achieve positive outcomes in the M-Banking application.

2. The convenience of the benefit has no bearing on M-Banking adoption intentions. This is because some M-Banking applications still require physical tokens; the Bank must be able to simplify this process. 


\section{References}

Ahmad, W., \& Sun, J. (2018). Modeling consumer distrust of online hotel reviews. International Journal of Hospitality Management, 71, 77-90. https://doi.org/10.1016/j.ijhm.2017.12.005

Ajzen, I. (1991). The theory of planned behavior. Organizational Behavior and Human Decision Processes, 50(2), 179-211. https://doi.org/10.1016/0749-5978(91)90020-T

Alba, J., Lynch, J., Weitz, B., Janiszewski, C., Lutz, R., Sawyer, A., \& Wood, S. (1997). Interactive Home Shopping: Consumer, Retailer, and Manufacturer Incentives to Participate in Electronic Marketplaces. Journal of Marketing, 61(3), 38. https://doi.org/10.2307/1251788

Beauchamp and Ponder. (2010). Perceptions of Retail Convenience for In-Store and Online Shoppers; Perceptions of Retail Convenience for In-Store and Online Shoppers. In 49 Marketing Management Journal.

Bender,W.C.(1964). Consumer purchase-costs-do retailers recognize them. Journal of Retailing, 40(1), 1.

Benoit, S., Klose, S., \& Ettinger, A. (2017). Linking service convenience to satisfaction: dimensions and key moderators. Journal of Services Marketing, 31(6), 527-538. https://doi.org/10.1108/JSM-102016-0353

Berry, L. L., \& Cooper, L. R. (1990). Competing with time-saving service. Business, 40(2), 3-7.

Berry, L. L., Seiders, K., \& Grewal, D. (2002). Understanding Service Convenience. Journal of Marketing, 66(3), 1-17. https://doi.org/10.1509/jmkg.66.3.1.18505

Chang, K., Chen, M., Hsu, C., \& Kuo, N. (2010). The effect of service convenience on post-purchasing behaviours. Industrial Management \& Data Systems, 110(9), 1420-1443. https://doi.org/10.1108/02635571011087464

Copeland, M. T. (1923). Relation of consumers' buying habits to marketing methods. Harvard Business Review, 1(2), 282-289.

Duarte, P., e Silva, S. C., \& Ferreira, M. B. (2018). How convenient is it? Delivering online shopping convenience to enhance customer satisfaction and encourage e-WOM. Journal of Retailing and Consumer Services, 44, 161-169.

Farida,N.(2016).Effects of convenience online shopping and satisfaction on repeat intention among students of higher institutions in Indonesia.Journal of Internet Banking and Commerce,21(2), 1.

Fishbein, M., \& Ajzen, I. (1975). Belief, Attitudes, Intention and Behavior: An Introduction to Theory and Research. Addision-Wasely, Reading: MA.

Gensler, S., Verhoef, P. C., \& Böhm, M. (2012). Understanding consumers' multichannel choices across the different stages of the buying process. Marketing Letters, 23(4), 987-1003. https://doi.org/10.1007/s11002-012-9199-9

Herrmann, R. O., \& Beik, L. L. (1968). Shoppers' movements outside their local retail area. Journal of Marketing, 32(4_part_1), 45-51.

Huang, P., Lurie, N. H., \& Mitra, S. (2009). Searching for Experience on the Web: An Empirical Examination of Consumer Behavior for Search and Experience Goods. Journal of Marketing, 73(2), 55-69. https://doi.org/10.1509/jmkg.73.2.55

Jebarajakirthy, C., \& Shankar, A. (2021). Impact of online convenience on mobile banking adoption intention: A moderated mediation approach. Journal of Retailing and Consumer Services, 58, 102323. https://doi.org/https://doi.org/10.1016/j.jretconser.2020.102323

Jiang, L. (Alice), Yang, Z., \& Jun, M. (2013). Measuring consumer perceptions of online shopping convenience. Journal of Service Management, 24(2), 191-214. https://doi.org/10.1108/09564231311323962

Jun, M., \& Palacios, S. (2016). Examining the key dimensions of mobile banking service quality: an exploratory study. International Journal of Bank Marketing, 34(3), 307-326. https://doi.org/10.1108/IJBM-01-2015-0015

Junglas, I., \& Watson, R. T. (2006). The U-Constructs: Four Information Drives. Communications of the Association for Information Systems, 17. https://doi.org/10.17705/1CAIS.01726

Kaura, V. (2013). Antecedents of customer satisfaction: a study of Indian public and private sector banks. International Journal of Bank Marketing, 31(3), 167-186. https://doi.org/10.1108/02652321311315285 
KIM, Y. E., \& YANG, H. C. (2020). The Effects of Perceived Satisfaction Level of High-Involvement Product Choice Attribute of Millennial Generation on Repurchase Intention: Moderating Effect of Gender Difference. The Journal of Asian Finance, Economics and Business, 7(1), 131-140. https://doi.org/10.13106/jafeb.2020.vol7.no1.131

Koenig-Lewis, N., Palmer, A., \& Moll, A. (2010). Predicting young consumers' take up of mobile banking services. International Journal of Bank Marketing, 28(5), 410-432. https://doi.org/10.1108/02652321011064917

Kollmann, T., Kuckertz, A., \& Kayser, I. (2012). Cannibalization or synergy? Consumers' channel selection in online-offline multichannel systems. Journal of Retailing and Consumer Services, 19(2), 186-194. https://doi.org/10.1016/j.jretconser.2011.11.008

Kumar, A., \& Kashyap, A. K. (2018). Leveraging utilitarian perspective of online shopping to motivate online shoppers. International Journal of Retail \& Distribution Management, 46(3), 247-263. https://doi.org/10.1108/IJRDM-08-2017-0161

Laukkanen, T. (2016). Consumer adoption versus rejection decisions in seemingly similar service innovations: The case of the Internet and mobile banking. Journal of Business Research, 69(7), 24322439. https://doi.org/10.1016/j.jbusres.2016.01.013

Lee, H., \& Jin Ma, Y. (2012). Consumer perceptions of online consumer product and service reviews. Journal of Research in Interactive Marketing, 6(2), 110-132. https://doi.org/10.1108/17505931211265426

Mahapatra, S. (2017). Mobile shopping among young consumers: an empirical study in an emerging market. International Journal of Retail \& Distribution Management, 45(9), 930-949. https://doi.org/10.1108/IJRDM-08-2016-0128

Mehmood, S. M., \& Najmi, A. (2017). Understanding the impact of service convenience on customer satisfaction in home delivery: evidence from Pakistan. International Journal of Electronic Customer Relationship Management, 11(1), 23. https://doi.org/10.1504/IJECRM.2017.10007745

Noble, S. M., Griffith, D. A., \& Weinberger, M. G. (2005). Consumer derived utilitarian value and channel utilization in a multi-channel retail context. Journal of Business Research, 58(12), 16431651. https://doi.org/10.1016/j.jbusres.2004.10.005

Reimers, V., \& Chao, F. (2014). The role of convenience in a recreational shopping trip. European Journal of Marketing, 48(11/12), 2213-2236. https://doi.org/10.1108/EJM-12-2012-0734

Roy, S. K., Shekhar, V., Lassar, W. M., \& Chen, T. (2018). Customer engagement behaviors: The role of service convenience, fairness and quality. Journal of Retailing and Consumer Services, 44, 293-304.

Shaheed, A. (2004). How convenience has changed the nation. Brand Strategy May (182), 44-46.

Shankar, A., \& Datta, B. (2018). Factors Affecting Mobile Payment Adoption Intention: An Indian Perspective. Global Business Review, 19(3_suppl), S72-S89. https://doi.org/10.1177/0972150918757870

Shankar, A., Datta, B., Jebarajakirthy, C., \& Mukherjee, S. (2020). Exploring Mobile Banking Service Quality: A Qualitative Approach. Services Marketing Quarterly, 41(2), 182-204. https://doi.org/10.1080/15332969.2020.1742982

Shankar, A., \& Jebarajakirthy, C. (2019). The influence of e-banking service quality on customer loyalty. International Journal of Bank Marketing, 37(5), 1119-1142. https://doi.org/10.1108/IJBM-03-20180063

Shankar, A., Jebarajakirthy, C., \& Ashaduzzaman, M. (2020). How do electronic word of mouth practices contribute to mobile banking adoption? Journal of Retailing and Consumer Services, 52, 101920.

Shankar, A., \& Kumari, P. (2016). Journal of Internet Banking and Commerce Factors Affecting Mobile Banking Adoption Behavior in India. In Journal of Internet Banking and Commerce (Vol. 21, Issue 1). http://www.icommercecentral.com

Shankar, A., \& Rishi, B. (2020). Convenience matter in mobile banking adoption intention? Australasian Marketing $\quad$ Journal 273-285. https://doi.org/https://doi.org/10.1016/j.ausmj.2020.06.008

Shareef, M. A., Baabdullah, A., Dutta, S., Kumar, V., \& Dwivedi, Y. K. (2018). Consumer adoption of mobile banking services: An empirical examination of factors according to adoption stages. Journal of Retailing and Consumer Services, 43, 54-67. https://doi.org/10.1016/j.jretconser.2018.03.003 
Sobti, N. (2019). Impact of demonetization on diffusion of mobile payment service in India. Journal of Advances in Management Research, 16(4), 472-497. https://doi.org/10.1108/JAMR-09-2018-0086

Tam, C., \& Oliveira, T. (2016). Understanding the impact of m-banking on individual performance: DeLone \&amp; McLean and TTF perspective. Computers in Human Behavior, 61, 233-244. https://doi.org/10.1016/j.chb.2016.03.016

Thakur, R., \& Srivastava, M. (2013). Customer usage intention of mobile commerce in India: an empirical study. Journal of Indian Business Research, 5(1), 52-72. https://doi.org/10.1108/17554191311303385

Wang, J., Yang, Z., \& Brocato, E. D. (2018). An investigation into the antecedents of prepurchase online Search. Information \& Management, 55(3), 285-293. https://doi.org/10.1016/j.im.2017.08.001

Wolfinbarger, M., \& Gilly, M. C. (2001). Shopping Online for Freedom, Control, and Fun. California Management Review, 43(2), 34-55. https://doi.org/10.2307/41166074

\section{Copyrights}

Copyright for this article is retained by the author(s), with first publication rights granted to the journal.

This is an open-access article distributed under the terms and conditions of the Creative Commons Attribution license (http://creativecommons.org/licenses/by/4.0/). 